\title{
El Obrador de Blas de Abila, Maestro Platero del siglo XVIII en Santiago de Guatemala
}

\author{
The Workshop of Blas de Abila, Master silversmith of the XVIII \\ Century in Santiago de Guatemala
}

Naiara Ardanaz-Iñarga

Facultad de Filosofía y Letras, Universidad de Navarra, España

*Autora a quien se dirige la correspondencia: nardanaz@unav.es

$\mathrm{E}_{t}^{1}$ libro El Obrador de Blas de Abila, maestro platero del siglo XVIII en Santiago de Guatemala es una publicación de la historiadora María del Carmen Muñoz Paz, investigadora del Centro de Estudios Urbanos y Regionales de la Universidad de San Carlos de Guatemala (Usac) realizada con el cofinanciado de

la Dirección General de Investigación, dependencia esta misma casa de estudios superiores, y constituye un resultado de la investigación "El arte de la platería y las familias de plateros Ávila y Guerra en la Nueva Guatemala de la Asunción, 1776-1820”.

El florecimiento del arte de la platería en la segunda mitad del siglo XVIII pone de manifiesto la prosperidad económica de la ciudad de Santiago, expresado en el interés por adquirir plata labrada por parte de las familias para manifestar su prestigio social, así como por parte de la Iglesia.

Los trabajos sobre platería en Guatemala se han desarrollado de modo paulatino desde la segunda mitad del siglo pasado. En el presente trabajo encontramos mencionados a especialistas como Alonso Rodríguez, Estéras Martín, Carrera Stampa, Samayoa Guevara o Abad Viela, pero también a los españoles, Angulo Íñiguez, Heredia Moreno, Sanz Serrano oMiguéliz Valcarlos.

El libro de María del Carmen Muñoz Paz combina algunos de los intereses que la autora ha desarrollado a lo largo de su carrera, la historia social, urbana, la labor de archivo como fundamento de lainvestigación histórica, así como la platería. Sorprende el enfoque de microhistoria que tiene este trabajo dedicado al obrador del maestro platero y grabador Blas de Abila y Quevedo, en el que los planos local, nacional e internacional se entrelazan de manera espléndida.
El primero de los cinco capítulos aborda aspectos más generales sobre la ciudad de Santiago de Guatemala en el siglo XVIII y la vida y características de las personas que ejercían el oficio de platero, sus talleres y gremios en los que se organizaban.

Los capítulos segundo y tercer se dedican al Maestro Platero, su residencia, obrador y familia a través del análisis documental del testamento redactado en 1767 y del inventario de bienes levantado tras su muerte en 1768. Dichos documentos han permitido conocer cómo era el funcionamiento y proceso productivo de uno de los talleres de platería más importantes de la ciudad; la interrelación de los distintos gremios; la no desestimable circunstancia de la localización de dicho taller, de hecho, clave para su próspero desarrollo, o el papel del maestro como cabeza de familia. La autora refleja cómo tenía lugar la formación de los oficiales y aprendices -también hombres y mujeres de su familia indistintamente. Relacionado con la mencionada posición de cabeza de familia del maestro, se analizan los espacios de poder, la capacidad de decisión que éste tenía sobre la emancipación de sus hijos y la aparición de sus nuevos talleres; así como el trabajo, la tutela y el lugar que ocupaban las hijas en las mandas testamentarias.

El cuarto capítulo trata sobre la red de clientes, comerciantes y personas que ocupaban destacados puestos en la administración, así como los vínculos con la iglesia. La autora selecciona acertadamente la trayectoria de dos importantes familias para analizar el consumo de la platería doméstica y litúrgica, en particular las encargadas al taller de Blas de Abila.

Para terminar, el quinto capítulo se centra en la identificación de algunas piezas de la obra del maestro 
Abila a través de un importante análisis documental y las técnicas y motivos decorativos empleados por él y sus descendientes. Se agradece que la autora entre de lleno en la discusión en torno al Legado de la Parroquia de San Martín de Lesaca, haciendo uso tanto de la documentación archivística, la bibliografía más actual y el análisis estilístico. Aborda cuestiones como la autoría, el marco cronológico y la pertenencia de piezas al correspondiente legado. Estas no son cuestiones sin importancia, ya que dicho legado - que se sigue conservando en la parroquia de aquella villa del antiguo reino de Navarra- es el ejemplo más significativo de platería procedente de Guatemala en toda la península. Tanto el conjunto de piezas como la trayectoria de la persona que los encargó, Juan de Barreneche y Aguirre, son temas que despiertan gran interés en la actualidad.

En resumen, esta publicación constituye un buen ejemplo de una concienzuda investigación realizada con distintas y muy interesantes perspectivas. En conjunto las imágenes de las piezas y documentos que se incluyen son de gran interés y apoyan la exposición y argumentación del trabajo. Por tanto, el presente libro puede resultar interesante para los especialistas en historia social, historia material y en particular los historiadores del arte que estudian la platería, pero por su clara y amena redacción también para un público no especializado.

\section{Datos editoriales del libro}

Autora: María del Carmen Muñoz Paz Título: El Obrador de Blas de Abila, Maestro Platero del siglo XVIII en Santiago de Guatemala Lugar y año de publicación: Guatemala, 2018 Casa editora: Universidad de San Carlos de Guatemala, Centro de Estudios Urbanos y Regionales, Dirección General de Investigación ISBN: 978-9929-738-73-7

Texto completo disponible en: https://digi.usac.edu.gt/edigi/pdf/P-2017-19.pdf

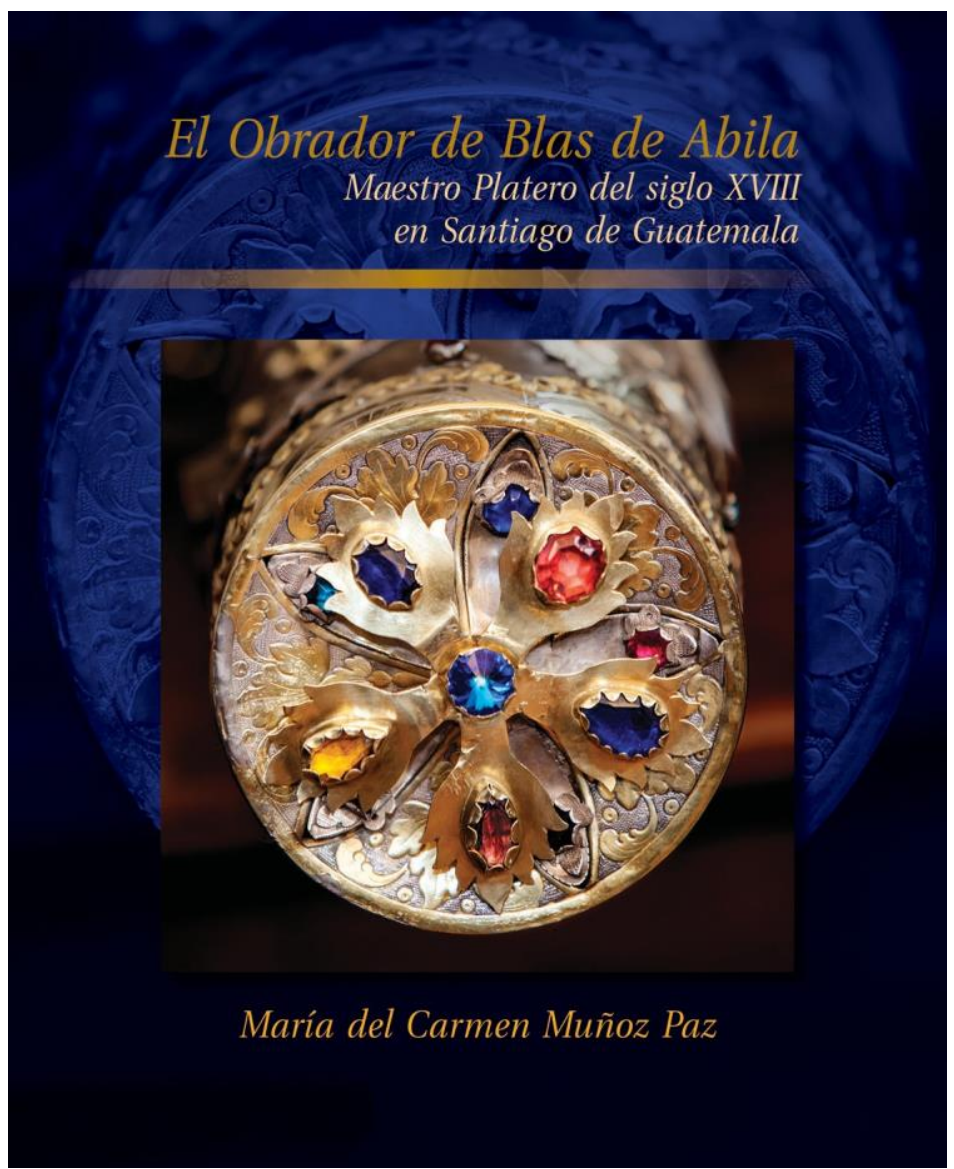

156
Figura 1. Cubierta del libro El Obrador de Blas de Abila, Maestro Platero del siglo XVIII en Santiago de Guatemala. 